\title{
Ortodoxia e coerência de um general (bom) de briga(da)
}

\author{
Paulo Ribeiro da Cunha
}

O marxismo ortodoxo não significa, pois, uma adesão sem critica aos resultados da pesquisa de
Marx, não significa uma "fé" numa ou noutra tese, nem exegese de um livro "sagrado".
A ortodoxia em matéria de marxismo refere-se, pelo contrário, e exclusivamente,
ao método. Implica a convicção cientifica de que, com o marxismo dialético, se
encontrou o método de investigação justo, de que este método só pode ser
desenvolvido, aperfeiçoado, aprofundado no sentido de seus fundadores;
mas que todas as tentativas para superar ou "melhorar" levaram
apenas a sua vulgarização, a fazer dele um ecletismo...

Gyorgy Lukács

Em seu último livro Tudo épolítica, Nelson Werneck Sodré sintetiza, numa breve passagem, o compromisso de uma vida intelectual associada a uma intervenção militante. E chama atenção para o fato de que "combatera o bom combate", ressaltando, em seguida: "já disse alguém e disse bem: quem não tem posição política não tem alma". ${ }^{1}$ É igualmente uma resposta isenta de lamentos a seus críticos e, talvez, por esta razão, o diálogo que ora iniciamos tenha o desafio de sinalizar para uma reavaliação do autor e sua obra, pautada em duas vocações - a do intelectual e a do militar, paralelas e confluentes -, bem como nas várias mediações de sua longa trajetória política. Algo, contemporaneamente, ainda objeto de vivas polêmicas e reflexões. Passados apenas dez anos de seu falecimento, em 1999, e às vésperas do centenário de seu nascimento, em 2010, percebe-se que alguns avanços na interlocução do autor com setores acadêmicos estão em curso; mas há razóes para supor que a polêmica ainda permanece, especialmente no diálogo com os militares. Vamos por partes.

Nos últimos anos, vários e importantes eventos acadêmicos sobre o historiador foram realizados e contribuíram para que o diálogo e o resgate de sua obra se refletissem na oxigenação do debate, possibilitando a emergência de mais de uma dezena de livros, teses e dissertaçóes, sem deixar de mencionar a constante reedição de seus livros seminais. Já entre os militares, essas considerações não encontraram a mesma ressonância. Vale registrar que sua obra contempla a publicação de 56 livros e inúmeros artigos e que, na condição de oficial de artilharia, Sodré teve uma longa trajetória no Exército, chegando à patente de General de Brigada. Mas, quanto a uma real apreensão de seus trabalhos no Exército, tratase de algo distante dos currículos de formação dos cadetes, aspirantes e oficiais. Se há alguma receptividade a seus livros entre os militares, ao que tudo indica, ela decorre mais de opçóes individuais de seus membros do que de uma política da arma.

Todavia, este ensaio tem por objetivo examinar uma questão polêmica - a democracia e os militares - e recuperar em sua obra alguns pressupostos para uma problemática futura. Nesta linha de análise, procuramos inicialmente valorizar uma particular apreensão no estudo da instituição Forças Armadas, sugerindo pistas para aquilo que é bem pouco conhecido ou estudado: a esquerda militar no Brasil. Trata-se, então, de procurar compreender os diferentes ângulos de apreensão do pensamento e da atuação de Nelson Werneck Sodré - o militar, o patriota, o comunista; a questão da democracia; o nacionalismo. Para esta reflexão, teremos necessariamente que buscar outras mediações em um diálogo com vários intelectuais. ${ }^{2}$

Uma primeira mediação seria a origem pequeno-burguesa de Sodré. Isto remete a um aspecto importante de sua trajetória política e de sua vocação militar, não sendo, no entanto, singular e, sim, uma característica de toda uma geração de militares no século XX, uma vez que o Colégio Militar e a Escola Militar eram as únicas possibilidades de muitos jovens estudarem e ascenderem socialmente. Há uma segunda questão correlata que se refere a uma característica pessoal do historiador, desde jovem: 
era um leitor voraz. A rigor, ele já era um intelectual em formação que ensaiava o exercício de sua vocação como escritor em alguns periódicos da época. Soma-se a esses aspectos um dado suplementar que muito influenciaria o jovem cadete: o papel da instituição Exército no período de sua formação. Esse aspecto foi determinante em sua obra e trouxe também a leitura de uma intervenção à esquerda, progressista, e até democrática do Exército em diferentes momentos da vida política brasileira. ${ }^{3} \mathrm{~A}$ rigor, as tensões históricas desse período refletiram-se de forma diferenciada nas várias instituições militares ao longo do século XX, sendo, portanto, impossível dissociar a formação daquela jovem oficialidade desse contexto, sobretudo, da influência dos tenentes, que queriam reformar e transformar a nação. Em suas várias expressões, o tenentismo também possibilitou uma singular politização na formação intelectual e ideológica de Sodré.

Por essa razão, procuramos neste ensaio desenvolver uma interpretação do tenentismo que apreendesse o movimento como "uma visão social de mundo" - de acordo com a formulação de Michel Löwy -, o que sugere uma visão generosa e, de certa forma, utópica do movimento, pois aqueles jovens militares acreditavam que, pela esfera da política, poderiam transformar o Brasil. Sob qualquer aspecto que analisemos este movimento, podemos observar que tratou-se de uma resposta política de uma geração de militares e que influenciou na formação de muitos futuros oficiais. A eles foram apresentadas, então, duas opções, isto é, duas correntes políticas, com projetos de intervenção antípodas: o Partido Comunista Brasileiro (PCB) e o Integralismo. Mas não somente: pensamos em um novo viés analítico, que envolve não apenas aqueles primeiros tenentes, mas também aqueles militares da geração pós-30 que foram influenciados por intelectuais marxistas e que pensaram a questão nacional.

Talvez, por isso, esta interpretação que incorpora Nelson Werneck Sodré ao debate, reflita uma embrionária terceira via. Nota-se aí uma diferença muito grande de enfoque, porque o pensamento marxista, já predominante naquele contexto, era chancelado pela Terceira Internacional e o pressuposto do internacionalismo. Entretanto, aludo aqui à influência de Plekhanov (entre outros pensadores marxistas) na formação nacionalista de Sodré, embora ele também tivesse um diálogo com intelectuais conservadores como Azevedo Amaral e Oliveira Vianna. Então, nessa terceira via, encontramos Nelson Werneck Sodré e uma geração de jovens tenentes, ou seja, neste período não se pode falar dele como marxista; materialista, sim; à esquerda, sim; mas não necessariamente marxista. Também não se pode deixar de assinalar que, por razões pessoais, ele não gostava de se expor publicamente, mas que, desde a sua época de aspirante, manifestava um forte desejo de intervir no país. Vale ainda ressaltar que Sodré não era organicamente vinculado ao PCB (isto aconteceria somente mais tarde), mesmo com a presença de células comunistas na Escola Militar. Desde jovem já demonstrava, inegavelmente, sua vocação intelectual; o período em que dirigiu a Revista da Escola Militar foi a época áurea do periódico. Contudo, uma indagação maior se apresenta: como podemos entender as razões de um intelectual e militar como foi o caso dele - para a sua guinada à esquerda?

Temos então, uma segunda mediação em relação à qual vale dialogar, mais uma vez, com Michel Löwy que, em um livro sobre a evolução política de Lukács, ${ }^{5}$ procurou enfrentar e desenvolver teoricamente a questão da opção pela esquerda por parte dos intelectuais, assim como as razões que induziriam um intelectual pequeno-burguês a assumir uma posição revolucionária. Acrescentamos mais uma indagação, ausente do arco proposto por ele: como um intelectual do Exército vivenciava essa problemática? O quadro, sob qualquer enfoque histórico, não era auspicioso para essa opção. Afinal, o Exército era uma instituição com uma tradição positivista, extremamente refratária a qualquer ideia de crítica ou de contestação à ordem vigente, tensionada até a medula pelo tenentismo e, depois, pelo levante de 1935, e blindada por uma cultura anticomunista - o que acarretaria, entre os militares de esquerda, não só problemas na carreira militar, mas também dificuldades na vida pessoal. Somente para registro: quase todos os militares de esquerda tiveram suas carreiras abortadas; bem poucos escaparam das cassaçōes iniciadas em 1964 e suas promoçôes, quando ocorriam, eram por antiguidade, como foi o caso de Sodré. 
Duas categorias explicativas, elaboradas por Löwy, contribuem para a compreensão daquela rotação: razões de natureza ético-cultural e político-moral. Essas orientações permearam a trajetória de Sodré e também a de vários tenentes, representando um elemento intrínseco da formação daquela geração de jovens indignados com a República Velha; jovens, de origem social pequeno-burguesa e que julgavam encontrar a possibilidade de transformação social por meio da filiação ao Exército. Aqui temos um ponto de inflexão central para entender o caráter democrático das Forças Armadas, ideário da qual Sodré nunca abdicou e que será objeto de exame em suas memórias, embora ele trate, mais especificamente, do Exército. ${ }^{6}$ Vale ressaltar que esse ideário passa pelas mediações ético-culturais e político-morais apontadas por Löwy, articulando-se com a origem social da maioria de seus membros, conforme podemos verificar pela própria trajetória intelectual e profissional de Nelson Werneck Sodré.

Essas mediações estão presentes conflituosamente, sob várias formas, em sua trajetória militar, desde sua ida para Mato Grosso, quando a práxis e a realidade histórica o ensinaram muito, ao ser confrontado com impasses éticos e morais, o que se refletiu em sua interpretação teórica e em sua prática profissional, em outros locais em que serviu. Isto explica como ele operava os instrumentos teóricos: muito de suas interpretações advém dessa práxis in loco. Vejamos, por exemplo, a tese do feudalismo, ou a da burguesia nacional; elas não se apresentaram em sua obra pela linha do PCB (ou da Terceira Internacional Comunista), até porque Sodré já refletia e escrevia sobre essas questões em sua juventude. Nesses dois casos, a práxis se apresentou concretamente para depois resultar na formulação teórica. Posteriormente, o instrumental marxista veio pavimentar as análises empíricas, ao longo de sua trajetória. Portanto, vincular suas teses ao PCB é um equívoco, uma vez que eram, fundamentalmente, teses de um tenente, substanciadas, depois, pelo referencial marxista, tendo muitas vezes seu autor se antecipado às leituras em voga. Coube a ele, por exemplo, o pioneirismo no Brasil na incorporação das ideias de intelectuais como Lukács - que norteia a $3^{a}$ edição de sua História da Literatura Brasileira - e Mariátegui, cujo pensamento fundamenta sua interpretação sobre a presença de relações feudais, no clássico Formação Histórica do Brasil.

Há, ainda, outras nuances muito curiosas em sua trajetória intelectual e militar. Durante o Estado Novo, foi um jornalista extremamente crítico ao regime, até porque os intelectuais com os quais convivia estavam na cadeia, ou no exílio. Mesmo assim, apoiava determinadas políticas do Governo Vargas. Como militar, entendia claramente que a integração do Brasil era necessária, pois se tratava de uma questão de segurança nacional, não se abstendo, por exemplo, de escrever artigos para Cultura Política, a revista do Estado Novo. Outros intelectuais de esquerda tiveram procedimentos semelhantes, o que sugere que, talvez, essa conduta fosse, naquela ocasião, a possibilidade possível de crítica. Posteriormente, em suas memórias, ele se arrependeria da colaboração no periódico estadonovista.

Sua autocrítica pode ser entendida, a partir de um tema constante em sua reflexão: sua concepção de política. Nos livros nodais para a compreensão deste aspecto - Memórias de um soldado e Memórias de um escritor, particularmente este último -, Sodré afirma, de modo categórico, que não tinha posicionamentos políticos. Isto é um equívoco, já que o historiador tinha, sim, posicionamentos políticos, ${ }^{7}$ mas, como vimos, eram resultantes da leitura e da visão generosa e ética de um tenente. Quando se examina sua guinada à esquerda, na Bahia, entre 1943-1944, verifica-se que ela ocorre, osmoticamente, quando de sua filiação ao PCB.

Neste sentido, uma outra particularidade dessa equação - Sodré, como militar de origem pequeno-burguesa, em sua nova condição de militante (ou de intelectual engajado) - é sugerida por sua percepção da política como compromisso moral. Nesse caso, podemos perceber que ele estabelece, com essa concepção, uma ruptura que é, na verdade, uma ruptura com continuidade. Observamos, igualmente, que a questão moral se apresenta como elemento nuclear para a compreensão de sua atividade intelectual e é determinante em sua atividade como militante comunista, já que, naquele momento, ele também passa a elaborar sua reflexão teórica com os referenciais marxistas. O conceito de moralidade do compromisso ${ }^{8}$ se apresenta como um componente fundamental para entender esta concepção política, antes e 
depois de sua entrada no PCB. Devemos considerar que essa mediação nos possibilita apreender a singular autocrítica que produz em relação à sua própria obra, bem como à sua trajetória militante, quando esta passa a ser mediada pela opção partidária.

De qualquer forma, para se entender sua guinada à esquerda, essas razões ético-morais e políticoculturais já confrontavam o autor em outras esferas e poderiam ser exemplificadas na crítica ao que denominou a "fascistização" do Exército. Ele emprega essa palavra para caracterizar as reformas de Góes Monteiro que feriam de morte direitos adquiridos ou estabeleciam critérios extremamente rígidos - em alguns casos, racistas - para a incorporação no Exército a partir da década de 1940. ${ }^{9}$ Esses aspectos, entre outros, forneceram a Sodré mais subsídios e uma nova reflexão sobre o significado da política. Mas não somente. Naqueles anos, quando servia em uma unidade de artilharia de costa, em Salvador, também ocorreu sua (re)aproximação com o pensamento marxista. Ali, ele encontrou um forte movimento de massas, como também núcleos comunistas atuantes, conhecendo então vários intelectuais. Anteriormente, tivera contato com Astrojildo Pereira e Graciliano Ramos, no Rio de Janeiro, mas, na Bahia, havia outro ambiente político, mais oxigenado, diferenciado do restante do país.

Por fim, ainda sobre os fatores que operaram para a sua guinada à esquerda, há necessidade de ponderar sobre a questão da esquerda militar, já que o PCB provavelmente foi, no Ocidente, o partido que mais teve militares em suas fileiras. Havia, inclusive, o Setor Militar - o Antimil -, fundado em 1929 para atuar junto às Forças Armadas e, na década de 1930, o Comitê Central era composto, em sua maioria, por militares. Para muitos deles, o PCB era o desaguadouro do ideário tenentista e isto significava a possibilidade de continuar, ou retomar, o projeto de mudança da nação, evidentemente com outros pressupostos. Há, todavia, um segundo aspecto relacionado. Não é possível uma compreensão desta problemática sem outra variável: Luís Carlos Prestes e seu prestígio entre os militares, algo até hoje muito pouco estudado, mesmo no Exército. Além disso, não é possível imaginar que Nelson Werneck Sodré tenha ingressado sozinho no Partido Comunista, àquela época, uma vez que, de fato, dezenas de militares aderiram ao partido, após a vitória da União Soviética sobre a Alemanha, acontecimento que trouxe o socialismo à ordem do dia. Um outro polo de adesão adveio de toda uma geração de combatentes da FEB, no retorno dos campos de batalha. Vale lembrar, ainda, os vários militares de 1935 que voltaram da Guerra Civil Espanhola, ou do exílio, como heróis e que se reincorporaram ao PCB.

Entre o final da Segunda Guerra Mundial e o início da Guerra Fria, mais exatamente em 1947, ocorre a cassação do PCB; os comunistas, em resposta, assumiram uma linha política bem mais à esquerda. Aqui há um ponto interessante para a reflexão: mesmo considerando que os dois Manifestos, o de 1948 e o de 1950, sustentavam que a revolução estava na ordem do dia, curiosamente, a maioria dos militares do Setor Antimil manifestava uma visão crítica acerca dessa formulação. Esta crítica não seria um caso isolado, já que o questionamento também ocorreu entre setores operários e intelectuais. Mas, entre os militares, quais foram os reflexos?

Na década de 1950, no bojo da campanha $O$ petróleo é nosso, o setor nacionalista venceu a eleição para o Clube Militar, e com ele, percebemos vários aspectos interessantes:

O candidato a presidente do Clube Militar expressava, naquele presente, a história e a tradição de luta de um passado da esquerda tenentista (alguns inclusive o pontuam com um ideário socialista), associado a um componente ético que forjara idealisticamente toda uma geração que teve o intuito de reformar a nação. Ao longo do Estado Novo, o General Estillac Leal pautaria sua conduta por vários posicionamentos políticos corajosos. Era, sem dúvida, um tenente. O candidato a vice, o General Horta Barbosa, que vinha se destacando na campanha "O petróleo é nosso", era o que melhor representava um projeto de nacionalismo como ideário de uma nação. Ambos os personagens, a meu ver, representam em grande medida, a continuidade do projeto tenentista. Um, representando a história; e o outro, a viabilidade modernizante e programática que até então faltava àquele ideário. ${ }^{10}$

A chapa nacionalista, além de vários militares ligados ao PCB, contava entre seus membros com o Major Nelson Werneck Sodré, como Diretor Cultural. É o momento em que sua intervenção política, 
para não dizer militante, se apresentou de forma confluente, em particular por meio de uma vigorosa intervenção na Revista do Clube Militar. Paralelamente à campanha pela criação da Petrobras, o exemplo mais significativo de um posicionamento que fez história, decorre da polêmica em torno da Guerra da Coreia e da possibilidade do envio de soldados brasileiros ao campo de batalha. Contrária a esta participação, a Diretoria do Clube Militar manifestou sua posição através de artigos e editoriais - entre eles, Consideraçôes sobre a Guerra da Coreia -, demonstrando, também, o caráter imperialista da guerra. Isto fez elevar as tensões entre os militares de forma inusitada.

Em suas memórias, Nelson Werneck Sodré afirma que não sabia do conteúdo daquele editorial. Mas julgamos que há grande possibilidade de ele ter sido um dos redatores. Para efeito da análise, vale considerar que já se percebia uma disposição, por parte da alta oficialidade conservadora do exército, para isolar a diretoria eleita. Se o editorial não tivesse sido o estopim, provavelmente teria sido encontrado outro motivo para a intervenção que ocorreu na entidade. Tanto é que a reação não se fez esperar: toda a diretoria do Clube Militar foi transferida, quase exilada, para guarnições distantes no país. Mas vale um registro: tratava-se de um compromisso político e ideológico de Sodré (e ele não foi o único) e de vários militares que assumiram aquele posicionamento à esquerda, sabendo das consequências que poderiam advir para suas carreiras. Eram, seguramente, tempos difíceis, e por quê?

As razões são bem conhecidas, bastando verificar a literatura anticomunista naquele período (e no subsequente, até os dias de hoje), embora, àquela altura, ganhasse fôlego inaudito uma nova campanha ideológica, resultante da Guerra Fria, atribuindo uma vinculação umbilical do PCB à URSS. Para um militar, o dever de servir à pátria constitui um atributo moral; esta dimensão de sua vida profissional e afetiva, quando recebe uma conotação negativa - a associação dos comunistas com outra "pátria", a URSS (na verdade, essa relação já era veiculada desde 1935) - talvez explique porque Sodré nunca tenha admitido ser comunista, assim como nunca o fizeram outros militares de esquerda. $O$ curioso é que Sodré apareceu no primeiro programa eleitoral do PCB, veiculado nos meios de comunicação, em 1985; esteve no aeroporto do Galeão recebendo Prestes, quando este voltou do exílio; e, ainda, escreveu com frequência nos jornais do partido. Entretanto, nunca assumiu a condição de comunista, publicamente.

Por paradoxal que possa parecer, é possível afirmar que o Setor Militar do PCB, no pós-1945 - mesmo com o partido posicionando-se politicamente à extrema esquerda - pautava-se por uma linha diametralmente oposta: a defesa da legalidade para a consolidação da democracia no Brasil. Os exemplos são muitos: os militares comunistas intervieram, de forma decisiva, na quartelada do General Lott, viabilizando a posse de JK; debelaram as revoltas de Jacareacanga e Aragarças, assegurando a posse constitucional de João Goulart, entre outros exemplos. Nessa tradição democrática e à esquerda, não foram eles que deram o golpe de 1964, nem foram eles que o apoiaram; praticamente todos, exceto em 1935, se posicionaram pela democracia e pela legalidade democrática. ${ }^{11}$

É nesta linha que podemos perceber, em Sodré, uma firme intervenção pela legalidade democrática. Nos muitos momentos de crise política, nas décadas de 1950 e 1960, escreveu dezenas de artigos sob o pseudônimo de Observador Militar no jornal Última Hora, com o firme objetivo de influenciar as Forças Armadas na conjuntura política nacional; em uma ocasião posterior, de forma quase explícita, escreveu contra o golpismo em curso no jornal Semanário, sob o pseudônimo de Coronel X, embora sua identidade não tenha passado despercebida para muitos leitores. Tentava, através dessa estratégia, veicular uma posição política a favor da democracia, sem assumir a posição de comunista, até porque não seria prudente criar antagonismos com a maioria dos oficiais legalistas das Forças Armadas, em particular os do Exército.

Polêmicas à parte, o historiador, àquela altura, já era um militante comunista e um militar que se destacava como intelectual no Instituto Superior de Estudos Brasileiros (ISEB). Nessa instituição, sobretudo, na última fase de sua história, antes do golpe de 64, Sodré (em cursos, pesquisas e livros) identifica o povo, de um ponto de vista teórico - como sujeito da história -, como componente axial de um projeto de nação. Esse período, no ISEB, é também aquele em que fundamenta suas teses com referen- 
ciais teóricos mais elaborados e publica seus livros seminais - Introdução à revolução brasileira (1958), Formação histórica do Brasil (1962) e História da burguesia brasileira (1964) -, todos com várias edições ao longo dos anos seguintes. Sem ilusóes quanto à continuidade de sua carreira militar, Sodré passaria para a reserva em 1962, com a patente de general de brigada, ainda no governo Goulart, procurando, a partir de então, intervir no movimento de massas no sentido de assegurar a democracia como expressão de um projeto nacional.

Por isso, sempre ressaltamos, em nossa interpretação, que, antes de comunista, ele era um tenente. Nelson Werneck Sodré encontra no PCB e no marxismo a continuidade do ideário tenentista. Como já afirmamos antes, o partido constituiu-se no desaguadouro de toda uma geração de militares de esquerda. Este aspecto é que veio a tornar-se marcante em sua trajetória. Evidentemente, em 1964, ele teve que fugir (como muitos), acabando por ser preso, depois, no interior de São Paulo. Quase toda aquela geração de militares foi cassada e as possibilidades de intervenção orgânica do Setor Militar do PCB, no interior das Forças Armadas, praticamente deixaram de existir, embora pequenos núcleos continuassem procurando influenciar no debate político nacional. Do ponto de vista intelectual, teve início, então, a fase mais rica da produção teórica do historiador.

Há, no entanto, outro aspecto que merece consideração. É bem provável que antes de ir para a reserva - quando desenvolvia suas atividades de ensino no ISEB e vivenciava o amplo movimento de massas que se verificou no país antes do golpe de 1964 - a reflexão que elaborou sobre as reformas de base tenha contribuído para o amadurecimento e aprofundamento de sua interpretação sobre o caráter da democracia e a questão democrática no Brasil. Com Formação histórica do Brasil, Sodré clarifica essas questóes em uma perspectiva revolucionária, ainda que no interior do arco teórico do debate marxista. Em suas palavras:

A defesa do regime democrático, no processo da Revolução Brasileira, não se prende, assim, ao supersticioso respeito a uma legalidade formal, mas na compreensão de que a democracia é o caminho apropriado ao seu desenvolvimento. Não interessa ao nosso povo, evidentemente, uma legalidade qualquer e uma democracia qualquer, mas o regime democrático efetivo cujo conteúdo esteja intimamente ligado ao desenvolvimento de alteraçôes econômicas, políticas e sociais capazes de afetar profundamente o país e corresponder ao avanço das forças produtivas que impōem modificaçōes radicais no modelo de produção. ${ }^{12}$

$\mathrm{Na}$ fase subsequente ao golpe militar, continuou com a atuação política e a reflexão teórica, particularmente intensas, ambas, após o advento do AI-5, em 1968. Ao longo daqueles anos, escrevendo artigos (muitas vezes sob pseudônimo) e livros e procurando intervir na luta pelo restabelecimento da democracia, seria uma referência contra o radicalismo e o aventureirismo pequeno-burguês que caracterizaram as iniciativas armadas de parcelas da esquerda brasileira na luta contra a ditadura militar. Embora tivesse singular e profícua produção teórica, teve igualmente um período de quase ostracismo em importantes círculos acadêmicos. Dessa época podemos contabilizar a publicação de alguns de seus mais importantes trabalhos sobre a relação entre militares e política, entre os quais se destaca a muito amadurecida e várias vezes postergada edição do já clássico História militar do Brasil, em 1965 - onde fundamenta, com argumentos sólidos, a tese do caráter democrático das Forças Armadas - e o monumental Memórias de um soldado, publicado em 1967. ${ }^{13}$

Ao longo dos últimos anos, pistas curiosas sobre a sua atuação política e militante naquele período começam a emergir em textos e ensaios. Num belo ensaio memorialístico, o historiador Ivan Alves Filho recupera algumas passagens da trajetória de Nelson Werneck Sodré e de suas atividades no PCB, na clandestinidade após o golpe de 1964, e comenta a existência de um trabalho, nunca publicado (e nunca encontrado), escrito por Sodré e seu pai, o jornalista e dirigente comunista Ivan Alves. Para Alves Filho, as relações de amizade entre ambos eram antigas e datavam da campanha $O$ petróleo é nosso. Nos anos seguintes, os laços de amizade entre o historiador e o jornalista se fortaleceram até que, com o golpe, Ivan Alves aceitou a proposta de Sodré de escreverem em conjunto um livro sobre o movimento político-militar de 1964. 
O texto do livro teria 80 a 100 laudas e dividia-se em duas partes: na primeira, Sodré analisava o início do regime, o seu caráter, de um ponto de vista mais estrutural. A segunda parte, redigida por Ivan Alves, continha uma análise de conjuntura e uma reflexão sobre a oposição ao regime militar que, naquela ocasião, já reunia crescentes setores da sociedade civil. Embora sejam desconhecidas as razões para sua não publicação, em 1966 (quando teria sido escrito), pouco tempo depois, um argumento político convincente, o AI-5, suspenderia definitivamente o projeto de edição. Ivan Alves Filho lamenta a ausência de qualquer notícia sobre o manuscrito, levantando a hipótese de que tenha sido queimado, ou que, talvez, possa estar, ainda, em algum porão do regime militar. Quando escrevia com Sodré, Tudo é política, e pesquisava no arquivo deste último, doado à Biblioteca Nacional, confessou que teve esperanças de encontrar os originais; em vão.

Neste ensaio - já examinando a situação de rigorosa clandestinidade do PCB - Alves Filho recuperou outra pouco conhecida dimensão política e militante de Sodré, que teria sido indicado para a suplência da direção do partido. Ele não sabe dizer se Sodré aceitou; contudo, a indicação qualificava-o, conforme suas palavras, "como uma das figuras de proa do PCB e, por conseguinte, da própria resistência democrática”. ${ }^{14}$ O fato teria ocorrido entre 1970 e 1971, mas lamentavelmente as informações fornecidas por Alves Filho são escassas e a lacuna também permanece, ou melhor, a informação está totalmente ausente nas memórias de Sodré, salvo algumas pistas muito discretas. A título de curiosidade, fontes orais diversas mencionam que houve uma outra obra não publicada, Memórias de um revolucionário, e que nela o autor reconstituiria a trajetória de sua militância comunista. Mas não há indícios concretos de sua existência, ou mesmo algum sinal de que o trabalho tenha sido realmente escrito. Se foi, talvez tenha se perdido em algum momento no pós-1964. Em seu vasto acervo doado à Biblioteca Nacional do Rio de Janeiro não há registro algum desta terceira obra memorialística que se articularia às demais - Memórias de um soldado (1967) e Memórias de um escritor (1970) -, como um legado à posteridade das múltiplas dimensóes da vida do historiador.

Nos últimos anos de sua vida, temos uma hipótese e alguns dados sobre a atuação política de Sodré, na transição democrática, e sobre o significado de sua última intervenção junto aos militares de esquerda. Ele atuou como militar e militante na luta pela anistia, pela democracia e pelo nacionalismo e, provavelmente, esta tenha sido, também, a última tarefa do Setor Militar do PCB, desempenhada, em grande medida, junto à Associação Democrática e Nacionalista dos Militares (ADNAM). A esquerda militar obteve relativo sucesso nesse processo, como algumas promoçôes e reintegrações, mas não avançou no objetivo de que seus integrantes fossem reincorporados às Forças Armadas. Na Constituinte, percebe-se, pelas anotações do historiador (preservadas em seu acervo pessoal) e pela atuação política da entidade, algumas tentativas de influenciar a elaboração da nova carta, no tocante ao papel dos militares. São os indicativos que temos para sugerir que sua presença foi significativa no cenário nacional e nos debates com os militares, na década de 1990.

Ao que tudo indica, assumiria, nesses últimos anos de vida, mais um desafio ou, quem sabe, mais uma missão ou, mesmo, uma última tarefa - e que, pela idade que já atingira, talvez, tenha sido a maior de sua vida. Do ponto de vista semântico, "tarefa" e "missão" são sinônimos. Todavia, seus significados são apreendidos de forma um tanto diferenciada nas instituições - o PCB e o Exército - às quais Nelson Werneck Sodré pertenceu. A principal tarefa que um militar pode receber é uma missão, algo que não se contesta e se realiza com disciplina e dedicação; já para o militante comunista, qualquer tarefa política é entendida como uma missão, realizada, com desprendimento, sob os mesmos pressupostos. Ainda assim, inegavelmente, missão e tarefa confluem e, em ambas as instituições, revestem-se de um caráter de nobreza.

Em seus últimos escritos, paralelamente às análises de conjuntura, percebe-se um último esforço que sintetiza os objetivos de sua rica trajetória intelectual e militar: reaproximar as Forças Armadas da sociedade civil. Se, de acordo com sua interpretação, as Forças Armadas eram parte constituinte do po- 
vo brasileiro, isto implicava, também, recuperar a concepção democrática do Exército. Para ele, na virada do século, as diferenças entre os militares do pré-1964 estavam completamente superadas; neste sentido, um esforço de (re)aproximação com a sociedade civil era mais do que necessário, uma vez que o desafio de repensar a nação estava na ordem do dia. O imperialismo, em sua versão neoliberal, era o inimigo maior que também se fazia presente. Daí, a perspectiva de uma Revolução Brasileira - naquela concepção de uma processualidade histórica que possibilitaria a superação de nossas debilidades - se apresentava, mais uma vez, na agenda nacional. Esta formulação, sem dúvida, significava a reafirmação dos princípios ideológicos que nortearam suas teses, mas também sua revalidação em outro contexto. Assegurar qual seria o espírito deste último desafio - missão ou tarefa - que norteou o general de brigada e historiador Nelson Werneck Sodré, nesta última e inconclusa fase de sua longa trajetória como intelectual e militar, ou mesmo militante, não é possível. Mas, ao que tudo indica, foi o seu último combate. O bom combate de um dos últimos tenentes.

\section{Revisão e edição: Maria Aparecida Rezende Mota}

\section{Notas}

${ }^{1}$ ALVES FILHO, Ivan (Org.) Tudo é politica: 50 anos do pensamento de Nelson Werneck Sodré em inéditos em livro e censurados. Rio de Janeiro: Ed. Mauad, 1988, p. 8.

${ }^{2}$ A tese central apresentada neste ensaio sobre o autor e sua obra foi desenvolvida em meu doutorado, sob a orientação da Profa. Dra. Elide Rugai Bastos. Para uma melhor compreensão dos argumentos, sugiro a leitura dos trabalhos de minha autoria citados na seção Referências.

${ }^{3}$ Opero com o conceito de esquerda militar desenvolvido em MORAES, João Quartim. A esquerda militar no Brasil: da conspiração republicana à guerrilha dos tenentes. São Paulo: Expressão Popular, 2005, p. 7.

${ }^{4}$ Como bem assinala Lowy: "Visões sociais de mundo seriam, portanto, todos aqueles conjuntos estruturados de valores, representaçôes, ideias e orientaçôes cognitivas. Conjunto esses unificados por uma perspectiva determinada, por um ponto de vista social, de classes sociais determinadas. As visões sociais de mundo poderiam ser de dois tipos: visões ideológicas, quando servissem para legitimar, justificar, defender ou manter a ordem social do mundo; visões sociais utópicas, quando tivessem uma função crítica, subversiva, quando apontassem para uma realidade ainda inexistente”. LÖWY, Michael. Ideologias e ciência social: elementos para uma análise marxista. São Paulo: Cortez, 1996, p. 13-4.

${ }^{5}$ LÖWY, Michel. Para uma sociologia dos intelectuais revolucionários: a evolução politica de Lukács (1909-1929). São Paulo: LECH, 1979.

${ }^{6}$ Para uma aproximação com este debate, sugiro a leitura do clássico de Nelson Werneck Sodré, História militar do Brasil (Civilização Brasileira, 1965).

${ }^{7}$ SODRÉ, Nelson Werneck. Memórias de um escritor. Rio de Janeiro: Civilização Brasileira, 1970, p. 124.

${ }^{8}$ Esta expressão é de Elide Bastos e Walquíria Leão Rego e remete a uma interlocução com a obra do autor e a uma singular linha de argumentação que valoriza a perspectiva do intelectual em sua relação com a política, na crença de que há uma relação entre sua atividade de pensar e um empenho moral no sentido de elevar a condição humana. As autoras ressaltam que a validade desse pressuposto está associada à sua atividade como um elo decisivo e possível para a transformação do mundo, como também para a emancipação da humanidade, impondo aos intelectuais uma condição: jamais renunciarem à sua condição de críticos. BASTOS, Elide Rugai e LEÃO REGO, Walquíria D. (Orgs.). Intelectuais e política: a moralidade do compromisso. São Paulo: Olho d'Água, 1999, p. 5.

${ }^{9}$ As mudanças realizadas por Góes Monteiro estabeleciam que os negros não poderiam entrar no Exército; eram também vetadas pessoas de origem operária, filhos de pais separados etc. Enfim, preconceitos que começaram a mutilar, no seu entendimento de militar, uma das bases da concepção democrática do Exército, algo que ele conheceu em sua juventude e que lhe possibilitou a ascensão social.

${ }^{10}$ CUNHA, Paulo Ribeiro da. Um olhar à esquerda: a utopia tenentista na construção do pensamento marxista de Nelson Werneck Sodré. Rio de Janeiro: Revan, Fapesp, 2002, p. 245.

${ }^{11}$ Considerando essa dicotomia, comunistas e democratas legalistas, quem nos auxilia a compreensão é o marxista inglês Ralph Milibanb. Ele demonstra que ser revolucionário é ter também uma concepção reformista, já que, contradizendo aque- 
la tradicional dicotomia reforma x revolução advogada por alguns setores marxistas, Miliband apreende o reformismo como expressão revolucionária. Nos militares, tal dicotomia pode ser entendida como uma política de confrontos, de conflitos, de forçar as instituiçôes, de forçar o debate, com o objetivo de aprofundar a democracia. Sobre esse debate, ver CUNHA, op. cit., p. 244 e seguintes.

${ }^{12}$ SODRÉ, Nelson Werneck. Formação histórica do Brasil. 9å ed., Rio de Janeiro: Civilização Brasileira, 1976, p. 402.

${ }^{13}$ SODRÉ, Nelson Werneck. História militar do Brasil. Rio de Janeiro: Civilização Brasileira, 1965. SODRÉ, Nelson Werneck. Memórias de um soldado. Rio de Janeiro: Civilização Brasileira, 1967.

${ }^{14}$ ALVES FILHO, IVAN. Meu amigo Nelson Werneck Sodré. In: CUNHA, Paulo Ribeiro da e CABRAL, Fátima (Orgs.). Entre o sabre e a pena: Nelson Werneck Sodré. São Paulo: Editora Unesp/Fapesp, 2006, p. 31-47.

\section{Referências bibliográficas}

ALVES FILHO, Ivan e SODRÉ, Nelson Werneck (Orgs.) Tudo é politica: 50 anos do pensamento de Nelson Werneck Sodré em inéditos em livro e censurados. Rio de Janeiro: Mauad, 1988.

BASTOS, Elide Rugai e LEÃO REGO, Walquíria D. (Org.). Intelectuais e politica: a moralidade do compromisso. São Paulo: Olho d'Água, 1999.

CUNHA, Paulo Ribeiro da. Um olhar à esquerda: a utopia tenentista na construção do pensamento marxista de Nelson Werneck Sodré. Rio de Janeiro: Revan, Fapesp, 2002.

CUNHA, Paulo Ribeiro da e CABRAL, Fátima (Orgs.). Entre o sabre e a pena: Nelson Werneck Sodré. São Paulo: Editora Unesp/Fapesp, 2006.

LÖWY, Michael. Para uma sociologia dos intelectuais revolucionários: a evolução política de Lukács (1909-1929). São Paulo: LECH, 1979. . Ideologias e ciência social: elementos para uma análise marxista. São Paulo: Cortez, 1996.

LUKÁCS, Gyorgy. História e consciência de classe. Rio de Janeiro: Elfos, 1989.

MORAES, João Quartim. A esquerda militar no Brasil: da conspiração republicana à guerrilha dos tenentes. São Paulo: Expressão Popular, 2005.

NETTO, José Paulo. Nelson Werneck Sodré. In: SODRÉ, Nelson Werneck. O Naturalismo no Brasil. Belo Horizonte: Oficina de Livros, 1992.

SODRÉ, Nelson Werneck. História militar do Brasil. Rio de Janeiro: Civilização Brasileira, 1965.

. Memórias de um soldado. Rio de Janeiro: Civilização Brasileira, 1967.

. Memórias de um escritor. Rio de Janeiro: Civilização Brasileira, 1970.

. Formação histórica do Brasil. 9a ed. Rio de Janeiro: Civilização Brasileira, 1976.

VIANNA, Marly de Almeida Gomes. Revolucionários de 35: sonho e realidade. São Paulo: Companhia das Letras/Expressão Popular, 1992. 


\title{
RESUMO
}

O presente ensaio tem por objetivo examinar alguns aspectos da obra e da trajetória politica de Nelson Werneck Sodré que, paralelamente à vocação intelectual, cumpriu longa carreira no exército chegando ao posto de General de Brigada. Autor de vasta obra sobre o Brasil, seu pensamento foi frequentemente associado à linha politica do Partido Comunista Brasileiro (PCB). Contudo, a interpretação que desenvolvo aqui é a de que suas teses foram elaboradas com base no movimento tenentista e no diálogo com teóricos marxistas, cujo eixo de análise constituia-se na questão nacional e não no internacionalismo vigente na Terceira Internacional. Sodré foi, também, um militante da Esquerda Militar, intervindo politicamente nas Forças Armadas e atuando decisivamente na defesa da legalidade democrática nas décadas de 1950 e 1960.

Palavras-chave: Nelson Werneck Sodré, esquerda militar, pensamento social brasileiro, Partido Comunista Brasileiro.

\begin{abstract}
This essay aims to examine some aspects of the ideas and political career of Nelson Werneck Sodré that, alongside the intellectual vocation, fulfilled a long career in the army reaching the rank of Brigadier General. Author of extensive oeuvre on Brazil, his thought was often associated with the policy of the Brazilian Communist Party (PCB). However, the interpretation I develop here is that Sodre's theses were based on movement lieutenants and dialogue with Marxist theoreticians, whose axis of analysis was on the national question and not on Third International internationalism. Sodre was also a militant of the Left Military, interfering politically in the Armed Forces and acting decisively in defense of democratic legality in the 1950s and 1960s.

Keywords: Nelson Werneck Sodré, Left Military, Brazilian social thought, Brazilian Communist Party.
\end{abstract}

